\title{
Pośrednictwo lekturowe - czytelnicze inspiracje w eseistyce Józefa Czapskiego
}

Daria Mazur 


\section{Pośrednictwo lekturowe - czytelnicze inspiracje w eseistyce Józefa Czapskiego}

I stotną część twórczości eseistycznej Józefa Czapskiego (kilkadziesiąt szkiców) stanowią tekstowe świadectwa recepcji literatury obcej autorów francuskich: Marie François-Pierre Gonthier Maine de Birana, Simone Weil, Marcela Prousta, Georgesa Bernanosa, François Mauriaca, Alberta Camus - i rosyjskich: Wasilija Rozanowa, Aleksego Riemizowa, Aleksandra Błoka, Aleksandra Sołżenicyna, Andrieja Siniawskiego. Jest to zbiór notatek do intelektualnej biografii emigracyjnego twórcy, zawierający wnikliwy opis rezonansu wywoływanego przez dzieła literackie, potwierdzający nie tylko uprzywilejowane znaczenie i micjsce aktu lektury w doświadczeniu egzystencjalnym, ale też silną potrzebę wypowiedzenia się w konfrontacji z odczytywanym tekstem, pisemnego utrwalenia procesu recepcji. Rozpatrując tę ścisłą zależność obu rodzajów aktywności, Joanna Pollakówna nazwala autora zbioru $C z$ ytając „homo scribens”', ponieważ gdy pisał o wybranych utworach, jeszcze wyraźniej wiązały się one z jego tożsamością. Świadomość dwukierunkowości procesu przenikania, swoistej osmozy życia i literatury, szczególnie wyostrzał kontakt z literatura intymistyczną; dlatego właśnie Czapski, zainspirowany przez Stanisława Brzozowskiego, przekonywal do lektury dzienników: "I nie warto ich czytać, jeżeli się ich również nie zasymilıje jako części własnej biografii"”.

Pisanie o książkach pozwalało na repetycję i gruntowną analizę własnych wrażeń, wynikało jednak także z potrzeby dzielenia się nimi, a więc shıżnia swoją refleksją autorom

\footnotetext{
'J. Pollakówna, O Józefie Czapskim, w: J. Czapski. Patrą ac, wyb. i post. J. Pollakówna, Kraków 1983. s. 393.

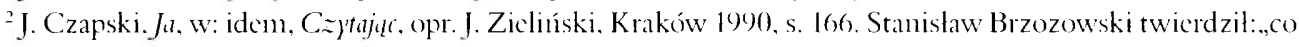
nic jest biografią — nic jest w ogóle" (S. Brzozowski, cyt. za: J. Czapski, ibidem). Autor Pamiętrika był obok: Cypriana Norwida jednym z polskich przewodników i inspiratorów refleksji moralnej. religijnej. historyczncj i kulturowej: jednym z autorów najczẹścicj czytanych i przywolywanych w escistyce Czapskicgo.
} 
i dziełom szczególnie zobowiązującyı. Ksztaltıjące się w ramach dialogicznej relacji autonomiczne obcowanie z literaturą prowokowalo wypowiedzi, które znamionuje ambicja wpływania na „horyzont oczekiwań”3 innych czytelników, rewidowania praktyki spolecznej odbiorców. Szkice Czapskiego, świadectwo osobistej recepcji, stanowią jej przedłużenie i przesądzają o jej aktywnym charakterze. Ujawnia się w nich wieloaspektowość oddziaływania literatury, złożoność procesu lektury w powiązaniu z przyjmowaną przez eseistę misją pośredniczenia w czytelniczych poszukiwaniach innego odbiorcy, który zyskuje zdwojoną perspektywę odniesienia - wobec interpretowanych przez Czapskiego utworów, a zarazem wobec jego refleksji ıı̣ętej w eseistycznej formic. Dlatego próba wskazania na indywidualne wlaściwości lektury emigracyjnego twórcy powinna odbywać się w kontekście zalożonej tezy o procesie, który można określić mianem pośrednictwa recepcyjnego.

W czytaniu, ukierunkowanym na poszukiwanie pokrewnego spektrum zainteresowań i korespondıjącej z własnym temperamentem odbiorczym temperatury myśli, ważnym aspektem był kragg inicjowanych przez ksiązki pytań i odpowiedzi, shużący rozwijaniu i poglębianiu namysłu nad obszarami leżącymi na styku egzystencji i metafizyki, życia osobowego i religii. Czapski posługiwal się w lekturze tajemniczym detektorem, pozwalającym rozpoznać i wybrać osobowości twórcze, których nieuporządkowanie, niepokój, rozdarcia nie wywoływaly zarzutów, a raczej stanowily o atrakcyjności ich koncepcji, gdyż cudze sądy nie zobowiązywaty do ostatecznych ustaleń i prowokowały do konfrontowania odmiennych punktów widzenia, aranżowania dyskusji między nimi ${ }^{+}$. Teksty emigracyjnego eseisty zdradzają również, że w przypadku wiclu utworów proces recepcji rozciągal się na lata: potwierdzają tym samym czytelniczą sklonność wracania do książek-kamieni milowych, stanowiących state odniesienie w pracy nad wewnętrznym ,ja” odbiorcy (taką rolę pełnity pisma Simone Weil i cykl IV poszukiuranin straconego czasu).

Trawestując słowa Prousta, jednego z ulubionych autorów Czapskiego, można powiedzieć, że celem lektury było „widzieć jasno w czytaniu” — dostrzegać innego człowieka, jego przeżycia i wezwanie, a nie tylko tekst literacki. Stąd też w szkicach, które znamionuje empatyczny ekspresyjny styl ${ }^{5}$, dalekich od jakiegokolwiek dydaktyzmu i moralizatorstwa, zaznacza się subtelna

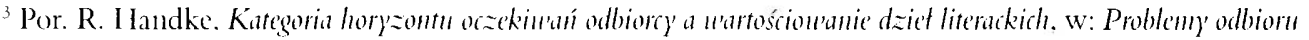
i odbiory. red. T. Bujnicki. J. Slawiński, Wroclaw 1977.

+ Tendencja ta zaznaczyla się szczególnic w budowic szkiców wykorzystujących ambiwalencję i antynomiczność tez autorów (w Ja - Mainc de Birana i Simone Wcil, Mauriaca i Rozanowa w Sprzézzlym ni-

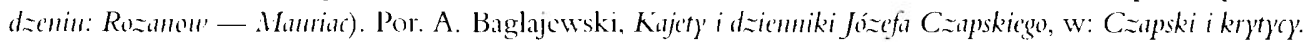
Antologia tekstón. wyb., opr. i post. M. Kitowska-Lysiak. M. Ujma, Lublin 1996. s. 425.

${ }^{5}$ Lektura Czapskiego, wykazująca pewne podobieństwo z opierającą siç na relacjonowaniu wrażeń wywolywanych przez dzicla „krytyką impresjonistyczną”, nosi też nicktóre cechy stylów wymicnionych w typologii Michała Glowińskiego. Jednak nic micści się w nicj ściśle. Bliski tej recepcji wydaje sį̣ styl mityczny, ze wzglę̧du na jego domenę — dzieła związane z santum, i styl ekspresyjny, ze względu na stosunek do autora. Znamionuje ją imnowacyjność, otwartość i nieprzewidywahność a więc cechy stylu wypracowancgo. Por. M. Glowiński. Śmiadectu'a i style odbiorn, w: idem. Style odbiorn. Szkice o komumikagi literackiej, Kraków 1977. s. 116-137.
} 
apelatywność, jako konsekwencja żywotnej w Europie tradycji czytelniczej. pojmowania literatury w kategoriach spotkania, dialogu, nośnika skali aksjologicznej". Współzalożyciel paryskiej „Kultury” nie pisat o swoich lekturach z pozycji krytyka zobowiązanego do reconzowania nowości wydawniczych, czytał bezinteresownie w porządku czasu wolnego, odrzucając gotowe scenariusze tak zwanej lektury modalnej. Nie interesowaly go książki blahe - niepożywne duchowo, nie trwonil czytelniczej energii na lektury modne, a gust w strategii odbiorczej Czapskiego nie spehniał roli drugoplanowej wobec wiedzy, kompetencji . Jednak bezsprzecznie jego eseistyczne krystalizacje zabiegów analityczno-interpretacyjnych potwierdzają status znawcy, a więc przedstawiciela tej warstwy publiczności literackiej, której wyróznikiem jest fakt przenikania opinii ksztaltowanych w jej ramach do szerszego środowiska czytelniczego ${ }^{8}$.

Szczegółowe analizy dyfuzji norm lcktury znajdıją się w spektrum badawczym empirycznej socjologii literatury; przyjmijmy jednak, że w przypadku Czapskiego, przy uwzględnieniu rozmaitych utrudnień (okoliczności wojny, ograniczenia PRL-owskiej cenzury, nikła dostępność w kraju prasy emigracyjnej), taka „międzywarstwowa wymiana — popularyzacja elitarnych wzorców czytania" miała i ma miejsce za pośrednictwem różnych kanałów. Istotną rolę odgrywają w tym procesie publikacje eseisty w różnych pismach (w przedwojennym „Przeglądzie Wspólczesnym” i „Wiadomościach Literackich”, w czasie II wojny światowej w „Orle Białym”, po wojnie w paryskiej „Kulturze”, a po październiku 1956 roku także w Polsce - w „Znaku”) oraz wydane w kraju (w roku 1983 jeszcze z ograniczeniami cenzury, zaś po przełomie 1989 roku już bez takowych) i na emigracji zbiory esejów ${ }^{\text {(") }}$.

Czytane książki byly również ważnym atrybutem prywatıych kontaktów, co wynikało z otwartej chłomnej osobowości i inteligencji dialogowej Czapskiego, zawsze gotowego zarazić rozmówców swoją fascynacją lekturową - często bardzo skutecznie. Czesław Miłosz właśnie za pośrednictwem przyjaciela z Maisons-Laffitte trafił na pisma Simone Weil, które potem thumaczyl i komentował" . Szczególnym świadectwem przenikania norm lektury

\footnotetext{
"Terminy stosowane w badaniach literackich w odnicsicniu do problematyki odbioru: spotkanic (Romana Ingardena), dialog (Michaila Bachtina). apel (Jeana Paula Sartréa), mają także swoje oduiesienia do koncepcji filozofii dialogu rozwijancj w Polsce przez ks. Józefa Tischnera. Por. 1). Mazur. Międey Ihśdhodem

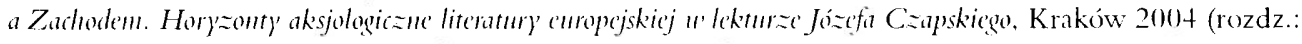

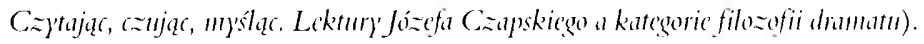

${ }^{7}$ Por. W. Karpiniski. Portret Canaskiegu, Wroclaw 1996, s. 119.

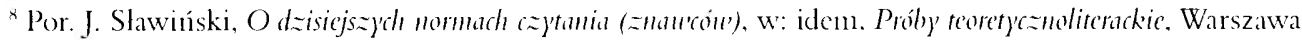
1992, s. 94-113.

"Ibidem, s. 106.

"'Zob. J. Czapski. Timmult i uridma, Paryż 1981 (wyd. krajowe: Kraków 1997): idem. Czytrając, op. cit.: idem. Patrzlc, op. cit.: idem, Surohoda tujemma, opr. A. Kaczýński. Warszawa 1991: idem, Rozproszone. Teksty' = lat 1925-1988, opr. P. Kądzicla, Warszawa 2005.

"Echa lekturowych inspiracji. którymi Czapski dziclil się z przyjaciólmi (byli wośród nich: Czesław Milosz, Gustaw I Icrling-Grudziński, Konstanty Jcleński, Wojcicch Karpiński. Adam Zagajewski) to temat na obszerne studium. W szkicach („Ir's our custom”; O Noruid sie) znajdujeny też ślady rozmów o książkach z obcokrajowcami. Por. W. Karpiński. Portret Carpskicgo, op, cit.. s. 183.
} 
Czapskiego jest szkic Cžytając Adama Michnika. Zdradza on okoliczności recepcji tekstów emigracyjnego twórcy, która miała miejsce w więzieniu podczas stanu wojennego, i naprowadza na interesujący wątek - wpływu zawartej w nich refleksji nad książkami na postawę moralną, na formowanie suwerennej osobowości odbiorcy w warunkach ekstremalnych, w sytuacji przymusowej izolacji ${ }^{2}$. Intrygujące jest, że tak znaczną silę oddziaływania mialy szkice wolne od jakichkolwiek doraźnych politycznych aluzji i ideologicznej tendencji.

Walorem czytelniczych komentarzy Czapskiego nie jest przeźroczystość, lecz osobisty ton, gdyż wybierat on utwory podejmujące kluczowe dla niego kwestie. Jednak autorskie ,ja” szkiców nie zasłania stematyzowanej lektury, a raczej poświadcza swoje w niej ukonstytuowanie. Eseistyka ta zdradza tajniki nowatorskiego, a zarazem obocznego systemu czytania, potwicrdza ambicję kształtowania i zmiany norm odbioru, wbrew tendencjom w obrębie stylów języka i ekspansji kultury masowej ${ }^{13}$. Usiłowania zmierzające do utrzymania pozycji literatury w kulturze, jej statusu jako duchowej inspiracji, wynikały ze świadomości związku pomiędzy upadkiem sztuki lektury i procesami, w wyniku których wartości podlegają atrofii. Czapski czytał przeciw spetryfikowanym, utartym wzorom i pożądanym modom. Prezentowana przez niego literatura sytııje się w opozycji do twórczości zorientowanej na komercyjny zysk, wspóltworzy istotny w kulturze XX wieku nurt, podejmujący kwestie zasadnicze dla świadomie egzystującego podmiotu - refleksji aksjologicznej i religijnej.

Ważnym czynnikiem wpływającym na styl czytania, charakteryzıjący się niezgodą na stereotypy odbioru i zdolnością aktualizowania tradycji literackiej, jest fakt, że Czapski to reprezentant szczególnej formacji intelektıalnej, która kształtowala się pod wpływem elementów kultury polskiej, myśli rosyjskiej, jak również ideowych prądów Europy Zachodniej'tt. Czytal on w oryginale książki zarówno rosyjskich, niemieckojęzycznych, jak i francuskich autorów, dokonywal też thumaczeń w ramach cytatów zapisywanych w dzienniku. Jego refleksja wyrosła z kresowego podglebia - z osobliwego terytorium pogranicza, ujmuje Europę jako wzrastający organizm, którego rozwój zależny jest od różnorodności przenikających się nurtów. Postawa łącząca krytyczną świadomość narodowej tradycji i chłonność, gotowość do podjęcia cudzego dziedzictwa, znajduje szczególny wyraz w poświęconych lekturom szkicach, które słuząa konfrontowaniu polskiego czytelnika z istotnymi dokonaniami curopejskimi i przybliżaniu dzieł nieznanych.

Znamiennym rysem eseistyki Czapskiego jest problematyka aksjologiczna i wyraźna postawa odczytywania utworów w perspektywie ku wartości. Odsłania się więc obraz re-

\footnotetext{
12 Zob. A. Michnik, Czytajqc. „Zeszyty Litcrackic” 1986. z. 13. Maria Janion poddała analizic to zagadnienie w odniesieniu do cyklı wykładów poświçconych Proustowi, wyglaszanych przez Czapskiego w sowicckich obozach internowania. Zob. cadem, Artysta przimicmienia, „Teksty Drugie”" 1991, nr 1/2.

"Por. J. Slawiński, Odbiór i odlhiona " procesie historycznoliterackim, op. cit., s. 92.

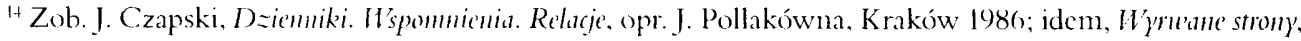
opr. J. Pollakówna. P. Kloczowski. post. J. Pollakówna. [Paris] 1993; idem, Süriat w moich oczach. rozmowy przeprowadzil P. Kloczowski, Ząbki-Paris 2001: M. Czapska, Eurow w rodzinic, wst. P. Ariès, post. K. A. Jcleński. Warszawa 1989.
} 
cepcji, formowany przez źródłowe pojęcia czerpane z wybieranych dziel, odzwierciedlający zarazem przyjmowaną hierarchię. Ujawnia się również ciągłość przeplatających się motywów, pokrewność postaw i sytuacji biograficznych, a nawiązania w twórczości różnych pisarzy potwierdzają wspólne (wschodnie i zachodnie) źródła kategorii wywiedzionych z europejskiej literatury. Ksiązki wzajemnie do siebie odsylają. Lektury rosyjskie ułatwiają odbiór rodzimych, a wybrani polscy autorzy (Norwid, Brzozowski) wskazują drogę kı nurtom sztuki zachodniej, prowokują do rekapitulacji wcześniejszych odczytań i recepcji nieznanych dziel rosyjskich.

Podmiotowość, walor ksztaltujący stosumek Czapskiego do literatury, wpłynął na wybór dziennika jako najbardziej interesującej formy, gdyż intymistyka obrazowała budzenie się świadomości nowożytnej tożsamości personalistycznej. Kluczowym dla namysłu nad dziennikanıi okazał się więc termin „osoba”, który, zgodnie z dwudziestowieczną refleksją rozwijającą koncepcję bytu osobowego, oznacza to, co najistotnicjsze i najcenniejsze w człowieku, co odróżnia go od rzeczy i zwierząt, dzięki czemu transcenduje on caly przedmiotowy świat, co jest zarazem celem i źródłem jednostkowego i społecznego życia istot ludzkich. Joumal intime Maine de Birana stanowil pasjonujący zapis metod introspekcji, przejawów duchowości poszukującej i niespokojnej, dążącej do samopoznania i szukającej uzasadnień metafizycznych. Nie anegdota czy opis obyczajów i historycznych przemian czyniły interesującymi zapiski filozofa, lecz dociekliwość, precyzja autoanalizy, odwaga odnotowywania sygnałów degradacji życia osobowego, odniesienia do takich kategorii jak sumienie, grzech, slabość, wola. Wątki te okazaly się one również istotne w refleksji Czapskiego nad francuską powiéscią katolickią.

Wyraźnie rysowała się analogia łącząca Journal intime' z metodą twórczą Prousta, którego cykl powieściowy wskazywał na droge poznania świata i innego czlowieka przez analizę wlasnych doznań, a więc studia nad ,ja”, służące docieraniu do bodźców zasadniczych, poszukiwaniu dominanty egzystencji. Czapski podkreśla:

u Birana to spojrzenie ,nieludzkie” jest whaściwie skierowane t y lko na świat wewnętrzny samego filozofa. Własną degradację, własną śmieszność notıje filozof równie beznamiętnie, z tą samą zimną drobiazgowością, z którą Proust przed śmiercią spisywal objawy własnej choroby, bo się mogły przydać do opisu śmierci Bergotte'a. To co Maine de Biran zapisuje w swym Journal intime, swoje cofanie się pamięci, sił skupienia, zdolności promieniowania, wnikając w swój świat wewnętrzny, jest niechybnie ścisłe ${ }^{15}$.

Czapski-czytelnik miał wyjątkową zdolność odnajdywania korespondencji między tekstami, które nierzadko dzieliły epoki. Nominalna dawność zapisków prekursora francuskiego spirytualizmu nie przeszkadzała rozpatrywać ich w kontekście dzieła Marcela Prousta

${ }^{15}$ J. Czapski, Ja, w: idem, Czytajlır. op. cit., s. 170. 
czy wojennych notatek Simone Weil, gdyż eseista czytał je w celu sformulowania, doprecyzowania wlasnych przekonań, nie zaś dla odniesień historycznych, studiów nad epoką. Maine de Biran okazywał się więc wspólczesny, korespondujący z wizją świata Czapskiego, a nawiązania poczynione w szkicu Ja mogły posłużyć wyrażeniu istotnych dlań kwestii: świadomości subiectum wzmocnionej kontemplacja istnienia w perspektywie transcendencji, trudności w analizie i werbalnym utrwaleniu doznań hierofanicznych, stanów mistycznych. Poszukiwania lekturowe eseisty obejmowaly dzicła autorów, dla których centrum bytu osobowego byla duchowość. Szczególną rolę spełniały pisma Maine de Birana i Weil, poświadczające drogę spirytualıej ewolucji jednostki w świecie nowożytnym; dominanta ta wspomagała namysł nad kondycją wspólczesnego człowieka i znamienną dla niej tendencją do odwrotu od źródel duchowych egzystencji, koncentracji na wymiarze materialnym.

Autorka Śuriadomości nadprzyrodzonej wnosiła do rozważań nad osobą postulat przyjęcia postawy poddania, przeciwnej religijności roszczenia, której centrum stanowi ludzkie égo i jego potrzeby. Jaźń objawiala się w koncepcji Biranowskiej jako wola, natomiast Weil, dyskredytując czynnik wolicjonalny, który należało opanować, wskazywala na nadrzędną rolę uwagi jako metody życia duchowego. Znaczenie tej kategorii potwierdzają zapiski dziennikowe Czapskiego, odnoszące się do inspirowanych koncepcją francuskiej myślicielki prób opanowania woli, pielęgnowania rytmu i dyscypliny wewnętrznej (dressage). Artysta, toczący bezustanną, nieslabnącą z wiekiem walkę o zmianę w sobie, który w obrazach i tekstach pozostawil świadectwa wnikliwej obecności w świecie, poprzez swój autentyzm i postawę nieustannej gotowości zmusza też odbiorcę do autorefleksji i uważnego oglądu rzeczywistości, przypomina o wadze koncentracji duchowej.

Wyraźnie zaznacza się w esejach Czapskiego świadomość konieczności tworzenia własnej moralnej rzeczywistości i wierności wobec przyjmowanej hierarchii wartości, na której szczycie, zgodnie z platońskim ideatem, winno znajdować się dobro. Lektura pism Weil okazała się pomocą w rozważaniu kondycji ,ja” aksjologicznego, podejmującego wędrówkę w stronę "horyzontu agatologicznego"16, gdyż konsekwencją stawianego przez francuską autorkę postulatu uwagi była teza o wyższym automatyzmie dobra:

Trzeba być obojętnym na dobro i zło, ale naprawdę obojętnym, to znaczy na jedno i drugie kierować jednakowo światło uwagi. Wtedy dobro zwycięża automatycznie. (...) Uwaga na najwyższym szczeblu jest modlitwą. (...) Jeżeli zwracamy inteligencję ku dobru, jest niemożliwe, by pomału cała dusza nie byla ku niemu porwana ${ }^{17}$.

\footnotetext{
1" Pojęcia te zaczerpniçte zostały z refleksji Tischnerowskicj. Zob. J. Tischner. Impresje aksjologiczne. w: idem, Suriat Indzkicj madzici. Kraków 1992, s. 162-168; idem, Filozofia dranatu. Hprouradzenie, Paris 1990, s. 53.

${ }^{\top}$ S. Weil, cyt. za: J. Czapski. Ja, op. cit., s. 177.
} 
Agatologiczne zagadnienia powracają także w związkı z twórczością Aleksandra Sotżenicyna i Alberta Camus, rozpatrywane w kontekście wolnościowych aspiracji czlowieka-osoby w spoleczeństwic i znamiemej dla systemu totalitarnego kondycji zniewolenia, przejawiającej się jako zgoda na odebranie prawa do udziału w wyborze dobra. W poświęconych tym kwestiom rozważaniach eseisty odbija się echo krytycznych poglądów Simone Weil i Georgesa Bernanosa, dotyczących uzależnienia jednostki od państwa.

Należy jeduak podkreślić, że odbiorcze ,ja” Czapskiego budowane i rewidowane przy pomocy refleksji nad lekturą niekiedy wchodzilo w spór z jej autorem. Wyrazistym przykładem jest niechęć do radykalizmu Weil. Neutralizıjąc ból, śmierć, trwogę, autorka Siły ciq̨żenia $i$ Łaski przekonywala, że w rzeczywistość cierpienia wpisany jest brak obecności jego znaczenia, i jako takie nie zasługuje ono na uwagę i wspólczucie. Oburzało Czapskiego prowadzące do anihilacji konsekwentne wyciąganie wniosków z założenia o zakłócaniu sobą harmonii świata. Śladem tych toczonych przez lata polemik jest inicjał „SW”, często powracający w Wyruanych stronach. Uważny czytelnik pism Wasilija Rozanowa nie mógh pogodzić się z przywoływanym przez żydowską myślicielkę platońskim ujęciem ciała-więzienia duszy, a jako malarz nie podzielał jej gnostyckiego urazu do materii. Jednak mimo tych rozbieżności w spotkaniu dwu różnych antropologii, warto paniętać o konstruktywnym przenikaniu wątków myśli Weil do refleksji Czapskiego, zdradzającej zdolność konfrontowania i lączenia różnych poglądów, przy zachowaniu wlasnej tożsamości.

Iteracyjny charakter miała rozlożona na lata recepcja $I V$ poszukin'aniu straconego czasu, którą w szkicu Mój Londy'n, przedstawiającym okoliczności pierwszego kontaktu z utworem, autor nazwał, intoksykacją" ${ }^{\prime 8}$. Czapski był jednym z pierwszych Polaków, którzy odkryli dzielo francuskiego pisarza i je komentowali. Studium Marceli Proust ${ }^{19}$, pisane w duchu Norwidowskiej krytyki służebnej, doskonale odzwierciedla znamienną cechę wypowiedzi eseistycznych - prywatność. Prezentuje ono oryginalny wizerunek pisarza, rozpoznawany w osobistym akcie lektury i niepoddający się ograniczeniom określonych systemów metodologicznych. Klucząc splątanymi ścieżkami biografii i dzieła, Czapski przyjmował rolę pośrednika w kontakcie mistrza i odbiorcy; pragnąl zarazić swą lekturową fascynacją, ułatwić zrozumienie Proustowskiego świata, a zarazem wyrazić wlasne twórcze credo.

Szczególna personalizacja i konkretyzacja idei związanych z recepcją $W$ poszukiu'anin straconego czasu objawiła się jednak w ekstremalnych okolicznościach wojny. Czapski wyglaszal dla wspólwięźniów w sowieckich obozach w Starobielsku, Pawliszczew Borze i Griazowcu wykłady o Prouście i jego dziele, snute po francusku z pamięci. Spisany przez towarzyszy niewoli i przethumaczony przez Teresę Skórzewską tekst prelekcji ukazal się

" J. Czapski, . Mój Londy'tr. w: idem. Patrąc, op. cit., s. 113.

"Zub. idem, Marceli Pronst, "Przegląd Wspólczesny" 1928. nr 1. Przedruk w: idem., Patrzac, op. cit., s. 9-29.

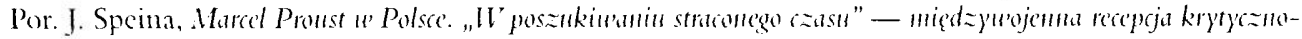
literucka, "Pamiętnik Literacki” R. 83: 1992, z. 2; J. Domagalski, Proust u' literaturze polskiej do 1945 rok'u, Warszawa 1995. 
w 1948 roku w „Kulturze”-”.". Prezentując powieść bez możliwości korzystania z niej, zweryfikowania cytatów, wykladowca poddał się działaniı pamięci mimowolnej, dzięki której odradzało się osobiste wspomnienie lektury. Stąd tèz w szkicu Protust u' Griazou obu obfite dygresje, anegdoty, reminiscencje pierwszego kontaktu z powieścią. Pa m i ęć, kluczowa w odczytaniu dzieła Prousta kategoria, spełniająca podobnie jak łaska w myśli chrześcijańskiej nadnaturalną funkcję, niosła ocalenie jednostkowe, jako niewidzialna strefa schronienia tak dla życia osobowego więźniów sowieckiego obozı, jak i dla odziedziczonej kultury, umożliwiając ludzkie wspólżycie i komunikację ponad traumatycznym doświadczeniem, które zdawało się ją przerastać. Stopnie drabiny pamięci wiodly w dól aż po fundament jestestwa człowieka. Intencja autorska, zasygnalizowana francuskim tytułem szkicu Proust contre la déchéance, potwierdza ten uniwersalny wymiar, gdyż poszukując nadziei, Czapski świadomie zestawiał takie aspekty dzieła, które wydawały mu się pomocą dla trapionego przez egzystencjalne niepokoje współczesnego czytelnika. W przekonaniu eseisty struktura cyklı IV poszukin'aniu straconego czasu naśladowała trudıy, umykający, lecz niezachwiany postęp prawdy, która rodziła się w świadomości narratora i potwierdzała w olśnieniu nadającym jej porządek i sens.

Przedstawione w studium Marceli Proust zjawisko przełamywania czasu historycznego przez uniwersalny czas sztuki i proces dojrzewania artysty, w którym krystalizuje się i sublimuje wyraz męstwa wobec trwogi i poczucia nicości, prowokowaly do osobistego doprecyzowania kategorii powotania. I Iumanistyczny imperatyw - przekonanie, że w siłach twórczych jednostki tkwi moc odradzająca - koresponduje z rozważaniami I Ienri Bergsona nad podmiotowością i pogrążającą się w materializmie kulturą, dla której ratunkiem według filozofa miała być refleksja mistyczna i ideał moralności heroicznej wzorowany na postawie Sokratejskiej. Podkreślający w swoim pisarstwie zależność sfer estetyki i etyki Czapski analizuje postawę twórcy oddanego dziełu i podejmującego wyniszczający wysiłek jako figurę egzystencji chrześcijańskiej (vita contemplatiıa), i potwierdza zarazem tezę, że „Dzielem sztuki w rozumieniu Prousta kieruje potrzeba metafizyczna”.'. Sens przekuwania materii w ducha jest odkrywany właśnie w powolaniu, a sztuka okazuje się drogą spirytualnej transcendencji. „Nie twórcą, ale thumaczem jest artysta, thumaczem prawd wiecznych"22 - pisze Czapski, i akcentuje możliwość poszerzenia interpretacyjnych kontekstów obrazów epifanijnych o odniesienia nadające im walor hierofanii, pozwalające odczytać je w perspektywie horyzontu metafizycznego. Przez pryzmat tego pojęcia eseista postrzegal sztukę, literaturę; czytał, poszukując znaków transcendencji, sygnalów naturalnej wrażliwości religijnej, osobistego stosunku do kwestii teologicznych.

2" Zob. J. Czapski. Pronst w' Gritzon'cu. tl. T. Skórzewska, „Kultura” 1948, nr 25-36. Przedruk w: idem, Cajtając, op. cit., s. I08-163. Zob. tez idem, Proust contre la déchéance. Lausanne 1987.

${ }^{21}$ A. Béguin, cyt. za: A. Maurois, Tr poszukin'anin Marcela Prousta, tl. J. Wachlowska, Warszawa 1961, s. 211.

22 J. Czapski. Marceli Pronst, op. cit., s. 22. 
Dziela francuskich powiésciopisarzy katolickich przynosiły odbicie ,ja” autorskiego, sytuowanego wobec religijnego światopoglądu, i umocowanie świata przedstawionego w doświadczeniu transcendencji, dziçki uchwytnej opozycji sacrum i profanmm. Charakteryzując strefę pogranicza świata laickiego i religijnego, obszar pisarskich analiz François Mauriaca i Georgesa Bernanosa, Czapski diagnozował symptomy kryzysu clırześcijaństwa: zeświecczenie świadomości, ekspansywne procesy desakralizacji (kultury, języka) ${ }^{23}$. Podejmowane we francuskich powieściach katolickich motywy, obrazıjące degradację pojęcia chrześcijańskiego su mien i a, upadek, grzech, osamotnioną świętość, osadzone były w realiach prowincjonalnych parafii, których mieszkańcy, skoncentrowani na zabieganiu o materialne dobra i zaspokajaniu potrzeby przyjemności, kreowali pragmatyczne sztuczne surogaty religii.

W świecie, w którym sacrum stało się nieczytelne, a spoleczne formy kultu nabierają często charakteru idolatrii (kult przyjemności, wodza, narodı, idei, idola), desakralizacja nie oznacza jednak desanktyfikacji - „najświçtsze” nie znika, jest natomiast zapoznane, zaprzeczone przez człowieka wspótczesnego. Takie zalożenie potwierdzają szkice poświęcone pomocnej w przywracaniu świadomości sacrum lekturze powieści Mauriaca i Bernanosa. Recepcja twórczości tych pisarzy okazywała się też szczególnie istotna w konfrontacji z niepokojącymi eseistę przejawami płytkiej, bezrefleksyjnej, poprzestającej na obrzędzie i oderwanej od sfery wyborów moralnych, ludowej religijności rodaków²t. Czapski jako czytelnik i interpretator powieści Bernanosa i Mauriaca, tworzący poświęcone im szkice od lat trzydziestych po lata siedemdziesiąte XX wiekı, prezentıjący zarazem panoramę wspólczesnej europejskiej religijności w kontekście uwarunkowań kulturowych i historycznych, sytuıje się w awangardzie myśli katolickicj ${ }^{25}$.

Tendencja dialogowa, zaznaczająca się w całej twórczości eseistycznej Czapskiego, znajduje szczególny wyraz w tekstach poświęconych autorom, których ojczyzną była „nieludzka ziemia”. Dawny więzień sowieckich łagrów, świadomy niechęci rodaków do poznawania i doceniania osiągnięć kultury rosyjskiej i prawosławia, podejmowal wysitek odsłonięcia bardziej złożonej wizji Rosji i jej dziedzictwa ${ }^{26}$. Kondycja rodzimej refleksji religijnej pro-

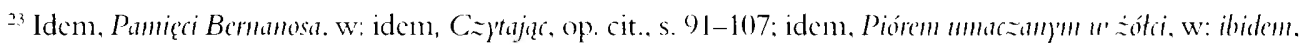
s. 202-206; idem, Sprzeczme uidzenie Rozamon - Manriac, w: ibidem, s. 272-337; idem, Śmicró Manriaca. w: ibidem, s. $4+5-+49$.

${ }^{2+}$ Por. idem, O Stanistanie Brzozarskim. w: idem, Patrzac, op. cit., s. 288-289.

25 Przyponnijmy, ze byl to czas powstawania przykościclnych ruchów i organizacji. formulowania zadań laikatı, następnic dyskusji. które inicjowaly postanowicnia II Soboru Watykańskicgo, a więc wyraźnych sygnalów odnowy wiary. rewizji tradycji chrześcijaństwa Zachodu.

2t Byl on wiçc kontynuatorem retleksji Norwidowskicj. postulującej wypracowanie otwartej i poznawczej relacji wobec Rosji. Zagadnicnic źródel i form przcjawiania się w twórczości Józefa Czapskicgo afirmacji trwalych wartości kultury rosyjskicj zostato szcrzcj omówione w artykule: I). Mazur, Józef Czapski - olkryuea wierancj i zwidhzonej Rusi, w: Polska w Rosji-Rosja w Polsce. Dialog kultur, red. R. Paradowski.

S. Ossowski, Poznań 2003, s. 103-115. 
wokowała go do poszukiwania, w różnych kręgach kulturowych, tekstów opartych na fundamencie teistycznym, rozwijających zagadnienia teologiczne w sposób autentyczny. Adoktrynalność, nieinstytucjonalny rys, skoncentrowanie na newralgicznych punktach: religii i życiu intymnym, które mają prymat nad problematyką społeczną, łączyły aforystyczne zapiski Wasilija Rozanowa i Andrieja Siniawskiego. W dziełach skłonnych do autoanalizy autorów, Czapski natrafiał na szerszą amplitudę, determinację, intymny i drastyczny sposób pisania o religii, utrwalone w tekście przejawy bogoiskatielstu'a, a także zakorzenienie namyslu nad duchowością w egzystencjalnej obserwacji.

Autor studium Sprzeczne widzenie: Rozanou' - Mauriac był jednym z pierwszych Polaków, którzy pisali o twórczości Rozanowa ${ }^{27}$. Znamienne, że Czapski nie traktował jej w kategoriach egzotycznej ciekawostki, lecz próbował rozniecić światopoglądową dyskusję polskiego czytelnika z kontrowersyjnym autorem, skonfrontować wschodnią żarliwość z letnią świadomością religịną rodaków. Rozanowowska formula „myślenia naskórkiem” jawiła się jako analogiczna do Proustowskiego „wrażenia jako narzędzia odkryć artysty”. Rosyjski przedstawiciel filozofii impulsu, przeciwstawiający się — podobnie jak Maine de Biran - materialistycznej, racjonalistycznej tendencji w myśleniu europejskim i odważnie lączący w poszukiwaniu eschatologicznego uzasadnienia wątku płci odległe tradycje (Egiptu, judaizmu, kultów telluryczuych), hipostazowal kategorie uczucia in at ury. Czapski konfrontował te koncepcje z poglądami równie skoncentrowanego na poszukiwaniu obietnicy zmartwychwstania Mauriaca, który jednak przeciwstawiał "świat katolicki” „Światu pożądań” i wyostrzał w duchu jansenistycznym ograniczenia natury ludzkieje2 ${ }^{28}$.

Natomiast w rozważaniach Rozanowa Bóg okazywał się nicią łączącą go ze światem, a postulowana pełnia człowieczeństwa oznaczała syntezę duchowości i cielesności. Akt strzelisty traktowany był jako sposób odnoszenia się do rzeczywistości, wyraz ukochania dziela stworzenia; dopelnialy się w nim porządki doczesny i transcendentny, co nie wynikało z panteistycznych załozeń, lecz poczucia związku pomiędzy relacją wobec osobowego Boga a stosunkiem do ludzi i natury. Kluczową zaś wartością, którą Czapski eksponowal, unikając uproszczeí i pozostając po kilkudziesięciu latach od pierwszej lektury wciąż wrażliwym na urodę języka, melodię zdań rosyjskiego autora i odwage jego metafizycznego namysłu, byl religijny indywidualizm. Postawa ta, sankcjonowana przez polskiego eseistę, wynikala z ducha teologii apofatycznej, podkreślającej wartość osobistej kontemplacji i utrwalającej w tradycji prawosławnej wzorce świętości osiąganej w bezpośrednim emocjonalnym kontakcie z Absolutem. 1) latego waśnie Rozanow nobilitował ludzkie uczucia jako źród to religijnego zachwytu.

\footnotetext{
27 W latach trzydzicstych powstało studium poświçconc twórczość Rozanowa, jednak Czapski uznal je za nie dość dopracowane i zrezygnowal z jego publikacji, przeredagowat je i wydat dopiero w 1958 roku w ,Znaku”. Zob. J. Czapski, Sprz'czme widz'nic Rosamou' - Manriac, op. cit.; idem, O, "Wylorze pism” Rozanow'a, w: idem, Cz)tajac, op, cit., s. 260-271: idem, (stosy = daleka, w: idem, Tummlt i widma, op. cit., s. $290-303$.

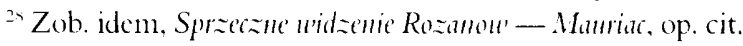


Wazkim kontekstem podejmowanej przez Czapskiego próby przyblizenia współczesnemu polskiemu odbiorcy refleksji kontrowersyjnego myśliciela był tragiczny związek jego biografii i losu spuścizny po nim. Rozanow umieral w nędzy w rewolucyjnej Rosji, a więc świecie, z którego wyrugowano ,jego" Boga i w którym zakazano wydawania jego dzieł. Innym autorem, którego twórcza biografia domagala się także rozpatrzenia, jako naznaczona tragizmem figura losu artysty, był rosyjski emigrant Aleksij Riemizow ${ }^{20}$. Lektura jego utworów wiązała się z pojęcicm t r a d y cji gwarantującej poczucie ciągłości, trwania, i wyostrzającej zarazem świadomość zagrożeń współczesności. Czapski, przeciwstawiając proponowaną przez Remizowa twórczą transpozycję dziedzictwa kulturowego instrumentalnemu traktowaniu tegoż dziedzictwa, ignorancji, megalomanii, nihilizmowi, nadal zmusza wspólczesnego czytelnika do określenia wlasnego stanowiska wobec zjawisk symptomatycznych dla oderwanej od źródel kultury masowej.

Oryginalność autora Cara Maksymiliana wyrażała się poprzez wybór tworzywa - folkloru ruskiego średniowiecza, podyktowany nie stylizacją (relacją estetyczną), lecz fascynacją powiązaną z motywacją światopoglądową. Apokryficzność oznaczała więc wierzeniowy tok opowiadania, w którym objawiał się metafizyczny wymiar treści. Autor licznych podaú, legend, apokryfów, bajek, nie kopiowal, nie stylizowal, lecz usilował wskrzesić, rekonstruować i uwspółcześnić mit (pra-tekst) pojmowany jako relacja świadka. Zainteresowanie formami staroruskimi prowokował neomitologiczny charakter prozy, opartej na próbach wnikania w istotę autorskiego ,ja” i jego kody pamięci. Interpolując, amplifikując elementy ludowego podania, sięgając, jak podkreśla Czapski, do tak odleglych źródeł jak sanskryt, tybetańskie tłumaczenia perskich baśni, ich wersje łacińskie, żydowskie czy interpretacje w językach europejskich, Remizow usiłował odstonić zdarzenie-archetyp, skryte pod narosłą w ciągu wieków warstwą przeobrażonego języka.

Jego dzieła przywracaly zanikającą w literaturze europejskiej świadomość realności i transgresji logosu. Twórczość Remizowa przenikato poczucie odpowiedzialności za stowo emitowane w świat, a ciężar aksjologiczny wypowiedzi wynikal ze świadoności jej ontologicznego umocowania ${ }^{30}$, gdyż pisarz pragnąl przybliżyć wspólczesnemu człowiekowi prajęzyk - narzędzie obcowania z prawdą o świecie. Czapski, dociekając istoty Riemizowowskiego rozumienia słowa, przywolywat eksplikacje odnoszące się do poetyckiego nacechowania, potencjału emocjonalnego, dźwiękowego, obrazowego i kontekstu oralnego (anakoluty, niezborność gramatyczna, wulgaryzacja). Wolność i spontaniczność języka autora Sióstr krzyżou'ych i Zu'idhzonci Rusi odsłaniała się w zderzeniu archaiczności, potoczności i nowatorstwa z czujnym zachowaniem wspóldźwięczności i rytmu. Urzeczony plastycznością prozy Remizowa, podobnie jak w przypadku Prousta i Norwida, Czapski

\footnotetext{
${ }^{213}$ Aspekt ten odgrywal równic istotną rolę w komentowaniu dzicl M. Prousta. C. K. Norwida i S. Brzozowskicgo. Zob. J. Czapski, Cedr, w: idem. Czjtajgc, op. cit., s. 338-343; idem, Montagnes russes, w: ibidem, s. 189-201: idem, H'spommicmia, .Kultura” 1953, nr 4, s. 123-126.

3" Por. A. Woźniak, Tradycja ruska u'edtug -Aleksego Riemizou'u. Lublin 1996, s. 37-53.
} 
przeciwstawiał twórczy, ożywczy stosunek rosyjskiego pisarza do słowa jego schematyzacji w ramach kultury masowej, zafalszowaniu i sfunkcjonalizowaniu, traktowaniu go jako narzędzie socjotechniki i poddaniu politycznym manipulacjom. Uczulał tym samym na stopień ,z-martwienia" naszej mowy ${ }^{3 !}$.

Refleksja nad sensem, wartością kategorii słowa i wyrażaną przy jego pomocy prawdą o rzeczywistości łączyła się też z zagadnieniem niesłużebności sztuki. Istotnym dopełnieniem namyslu nad kategorią s wo body t wó r c z ej w eseju poświęconym Aleksandrowi Błokowi, diagnozującym źródla i konsekwencje tragicznego uwiedzenia przez ideologię, są teksty, w których Cizapski poddaje analizie konteksty polityczne i historyczne literatury w odniesieniu do postaw Aleksandra Solzenicyna i Alberta Camus ${ }^{32}$. Łączy ich zaangażowanie podczas probierczych okresów, uczestnictwo w rzeczywistości społeczno-politycznej, wynikające z autoświadomości (w ich dziełach rozpoznanie ,ja” znaczy bycie wolnym) i z glębokiego przekonania o możliwości zarażenia zlem. Camusowska „epidemia” stawia czlowieka przed koniecznością wyboru: ucieczki, zgody, buntu. I tylko kluczowa w koncepcji autora $D \dot{\Sigma} m m y^{\prime}$ postawa niezgody na zainfekowaną egzystencję oznacza zachowanie i ochronę przestrzeni wolności, gdyż właśnie w jej obszarze możliwy jest w y bór dobra. Walka ze złem, jako odrzucenie postawy beznadziei, mające źródło w poczuciu solidamości z drugim czlowiekiem i ze światem, jest formą podjęcia wolności.

Przyblizając polskiemu czytelnikowi w roku 1947 problematykę powieści Dżuma w kontekście Listı do przyjaciela Niema, Czapski odczytywal egzystencjalizm Camusa w perspektywie personalistycznej. Szukał uzasadnienia tezy, że francuski pisarz w wyniku doświadczenia totalitaryzmu, odrzucając sankcję religijną dla postawy moralnej, przyjął dla antropologicznej refleksji nad bytem osobowym fundament aksjologiczny prowadzący do etosu heroizmu. Ścieżki egzystencji, postawy prezentowane w Dżumie potwierdzały, że doświadczenie zniewolenia, ograniczające i ukierunkowujące aktywność, nie likwiduje hierarchii aksjologicznej i nie uwalnia od decyzji, akcentuje jedynie jej tragiczny wymiar. Czyniąc ,ja" ośrodkiem dialektyki dobra, Czapski rozważał również zaznaczającą się w twórczości Sołżenicyna niezgodę na istnienie w trwodze, pojmowana jako przeciwstawienie prawdy słowa systemowi totalitarnemu opartemu na kłamstwie i przemocy, jako związaną z nakazem moralnym postawę wiary (rzecznikami religio jako głęboko etycznej więzi są postaci Aloszki z Jednego dnia Iwana Denisouricza i Silina z. Archipelagu GULag). Zagadnienia rozpatrywane w esejach poświęconych twórczości Camusa i Sołżenicyna wydają się nadal aktualne i dają się oduieść do rzeczywistości posttotalitarnej; świat po epidemii także stawia czlowieka wobec konieczności wyboru, tym bardziej niezbędnego, im silniejsza jest w nim świadomość ponownego zagrożenia — powrotı „dżumy”.

${ }^{31}$ Zob. J. Czapski, Montagnes risses, op. cit., s. 191.

32 Idem. Btok i suroboda tajemma, w: idem. Suoboda tajemma, op. cit. s. 121-128; idem, La Peste, w: idem, Czz-

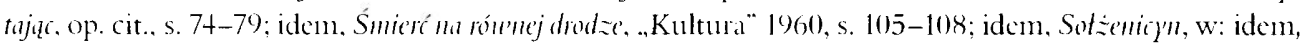
Tiumult i uidma. op. cit., s. 322-327. 
Wybierane przez Czapskiego dzieła składają się na kanon, którego formula zrodziła się z przeświadczenia, że w kulturze europejskiej ostatıich stu pięćdziesięciu - dwustı lat utrwalone zostały dzieje ,ja”, jego wędrówki ku horyzontowi metafizycznemu, jego zmagań z historią oraz usiłowań ukonstytuowania i zachowania wyrazistego oblicza aksjologicznego. Mistrz rozumiejącego, empatycznego czytania pisal o lekturach, by własną biografia duchową poświadczyć żywotność dzieł i w osobistej formie ukazać ich wartość kulturową. Stawiając literaturę wobec wartości, formulował tezy odnoszące się do różnych autorów, których wiązała sieć zależności charakterystycznych dla dialogowej inteligencji wnikliwego czytelnika, zdolnego łączyć sprzeczności, a zarazem wrażliwego na specyfikę tembru głosów interesujących go twórców. I Iermeneutyczne koło lektury pozwalało coraz wnikliwicj komentować, rozumiéć oraz przekładać to rozumienie na wlasne zadania twórcze. 